\title{
At lære at reflektere
}

\section{Brug af teknologi til at facilitere refleksion i en blended kontekst}

\author{
Betina Leth Leth, VIA University College \\ Bente Riis, VIA University College \\ Lillian Buus, VIA University College
}

\begin{abstract}
Denne artikel belyser hvordan kliniske vejledere inden for det sundhedsfaglige felt kan stimuleres til at reflektere over egen praksis ved at anvende simulering. Formålet har været at undersøge, hvorvidt der skabes refleksion og i særdeleshed 2. ordens refleksion, når refleksionsprocessen understøttes af teknologi. Artiklen er udsprunget af et følgeforskningsprojekt, som ser på ibrugtagningen af et simulationsprogram, som faciliterer refleksion. Gennem analyse af observationer, spørgeskemaundersøgelse og fokusgruppeinterviews belyses en række didaktiske overvejelser. I artiklen konkluderes det, at anvendelsen af teknologi giver mulighed for at arbejde på et individuelt niveau, i eget tempo samt gentage efter behov. Ligeledes skabes mulighed for visualisering og dermed en oplevelsesorienteret og spejlende tilgang til læring. Yderlig har analysen vist at forstyrrelser er nødvendige for at skabe 2. ordens refleksion, hvilket viser sig svært for de kliniske vejledere, men at teknologien og den efterfølgende debriefinger understøtter denne proces. Dog konkluderes det også, at simulationsprocessen igangsætter forskellige refleksionsformer, og at nogle af refleksionsformerne i sig selv kan fungere som barriere for 2. orden refleksion. Sidst men ikke mindst kan teknologi være med til at sikre, at alle er aktive og deltagende.
\end{abstract}

\section{Engelsk abstract}

This article describe how Clinical supervisors in the field of health care can be stimulated to reflect on their own practice by using simulation. The purpose has been to investigate whether reflection and, in particular, second-order reflection are created when the reflection process is supported by technology. The article arises from a research project that looks at the commissioning of a simulation program that facilitates reflection. Through analysis of observations, questionnaires, and focus group interviews, a number of didactic considerations are clarified. The article concludes that the use of technology provides the opportunity for the Clinical supervisors to work at an individual level, at their own pace and to repeat as needed. Likewise, opportunities for visualization and thus an experience-oriented and reflective approach to learning are possible. Further, the analysis has shown that disturbances or irritations of the mental status quo are necessary to create second-order reflection, which turns out to be difficult for Clinical supervisors but that the technology and the subsequent debriefing support this process. However, it is also concluded that the simulation process initiates different forms of reflection, and that some of the reflection forms in themselves can act as a barrier to second-order reflection. Finally, yet importantly, technology can help ensure, that all participants are active and involved. 


\section{Introduktion}

Professionsuddannelserne er præget af kompleksitet og foranderlighed (Brøbecher \& Mulbjerg, 2010), hvilket stiller høje krav til de sundhedsfaglige medarbejdere. De skal hele tiden udvikle og gentænke deres praksis og skabe nye løsninger. At skulle gentænke praksis, lære at lære eller omlære kræver, at de mentale skemaer revurderes og eventuelt helt eller delvis nedbrydes og rekonstrueres (Wahlgren, Høyrup, Pedersen, \& Rattleff, 2013). I den proces bliver refleksion et centralt begreb, ligesom refleksion også er centralt i læringsmålene for diplom- og professionsuddannelse (Uddannelses- og Forskningsministeriet, 2016 §14). Inden for uddannelsessektoren (Professionshøjskolen Absolon, 2013; "VIA Aftryk", u.å.) er der generelt, stort fokus på design af nye læringsformer og tilrettelæggelse af undervisning på nye måder understøttet af teknologi. Baseret på en blended læringstilgang (Conole, 2007; Gynther, 2005), og en digital tilrettelæggelse, der understøtter en flippede learning kontekst enten i undervisningen eller inden (Hachmann \& Holmboe, 2014, 2015), er forløbet, som beskrives i artiklen med til at understøtte den digitale uddannelseskultur, som efterspørges mere og mere.

En af udfordringerne, når der tales om refleksion (i praksis), er hvordan fundamentet til at kunne reflektere f.eks. ind i en 2. ordens refleksion skabes, når der arbejdes med udvikling af praksis og nye former for læring i en digital kontekst. Et interessant spørgsmål, der rejser sig i relation til refleksion, når fokus er på teknologiunderstøttelse er, hvordan der skabes teknologisk didaktiske løsninger? Didaktiske løsninger, der har fokus på refleksion, og som kan understøtte en dybere refleksion, der sætter de grundlæggende antagelser, værdier og holdninger i spil.

\section{Formål}

Artiklen er baseret på et følgeforskningsprojekt, som er en del af et større flerårigt projekt om "Refleksiv tænkning gennem simulation" ("Refleksiv tænkning gennem simulation - University Colleges", 2011), hvilket kort er skitseret i "Baggrund”.

Formålet med følgeforskningen var, at undersøge, hvordan de kliniske vejledere oplevede en digital understøttet simulationsproces i relation til egen læring, og hvorvidt de oplevede, at der blev skabt refleksion og især 2. ordens refleksion. Derudover skulle følgeforskningen være medvirkende til at undersøge en række umiddelbare hypoteser omkring teknologi i undervisningen, så som hvorvidt teknologi giver mulighed for at arbejde på et individuelt niveau, mulighed for at arbejde i eget tempo og gentage efter behov. Derudover også hvorvidt teknologien skaber mulighed for visualisering som en læringsstil og dermed skaber en oplevelsesorienteret og spejlende tilgang til læring, samt bidrager til, at alle er aktive og deltagende.

Artiklen baserer sig på de resultater, som følgeforskningen har frembragt og belyser, hvorvidt der gennem en simulationsproces skabes refleksion hos kliniske vejledere, samt hvilke muligheder for 2. ordens refleksion, der opstår, når læreprocesser understøttes teknologisk i en blended kontekst. Yderligere er der i artiklen set på, hvordan teknologi kan understøtte læringsmålet i forhold til at styrke kliniske vejleders refleksion og om de indledende hypoteser er holdbare.

\section{Baggrund}

I forbindelse med det overordnede flerårige projekt "Refleksiv tænkning gennem simulation" blev der udviklet en prototype af et simulationsprogram, som skulle afprøves i forskellige praksiskontekster. På VIA var det inden for modulet 'Klinisk vejledning i sundhedsfaglige professionsuddannelser', hvor formålet var at "fremme de kliniske vejlederes refleksion gennem simulation hhv. fremme programkonstruktørernes refleksion gennem udarbejdelse af programmet.” (Schaarup, 2017, s. 7). 
Hypotesen var, at 2. ordens refleksion er svært for professionelle at gøre i egen velkendte praksis, og der skulle en forstyrrelse til for at igangsætte 2. ordens refleksioner.

Overordnet set kan simulering bruges til at skabe situationer, som er så virkelige som muligt, og som giver deltagerne mulighed for at udfolde deres evner og kompetencer på en måde, som ikke umiddelbart er eksplicit (Srinivasan, Hwang, West, \& Yellowless, 2006). Teknologi kan bruges til at understøtte simulering. Især er videoer eller narrativer anvendt til at skabe scenarier, der afspejler sider af virkeligheden, som personer efterfølgende skal forholde sig til og f.eks. reflektere over egen praksis ud fra. Ofte er simulation forbundet med udviklede platforme og systemer, som vil kunne reagere på et input, og der vil via algoritmer i et computer system ske et output baseret på det givne input (Jones, Passos-Neto, \& Braghiroli, 2015; Perez, 2016). Den form for simulering, der refereres til i denne artikel, er baseret på en tilgang, hvor der skabes forestillinger. Deltagerne lever sig ind i forskellige narrativer og forestiller sig deres egen rolle i situationen (Andersen, 2010). Teknologien skaber her muligheder for dels forskellige visuelle scenarier som kan igangsætte refleksion, dels muligheden for gentagelse. Med en forståelse af blended learning som værende "...the organic integration of thoughtfully selected and complementary face-to-face and on-line approaches and technologies" (Garrison \& Vaughan, 2008, s. 148; Nyvang \& Dau, 2013), har formålet med inddragelsen af et simulationsprogram på klinisk vejleder moduler været at skabe et blended læringsforløb for de kliniske vejledere. Et forløb med mulighed for refleksion og forstyrrelser, og hvor der skabes grundlag for at bevæge sig fra 1. til 2. ordens refleksion.

Forløbet omkring simulationsprocessen består af 3 faser:
$*$
Fase 1: Briefing - indledende instruktion til simulationsprogrammet og processen
*
Fase 2: Gennemgang af simulationsprogrammet (foregår online i klasselokalet)
*
Fase 3: Debriefing - efterfølgende opsamling på klassen og facilitering af refleksion i grupper.

Formålet med den simulation, der er udviklet i projektet, skal ikke tjene til at opøve specifikke færdigheder, eller generere viden med rigtige og forkerte svar. Her skal simulationsprogrammet være med til at stimulere til refleksion, hvor det i højere grad er ens værdier, holdninger og antagelser som bliver sat i spil, og gjort bevidste for den enkelte.

Simulationsprogrammet er opbygget på følgende måde:

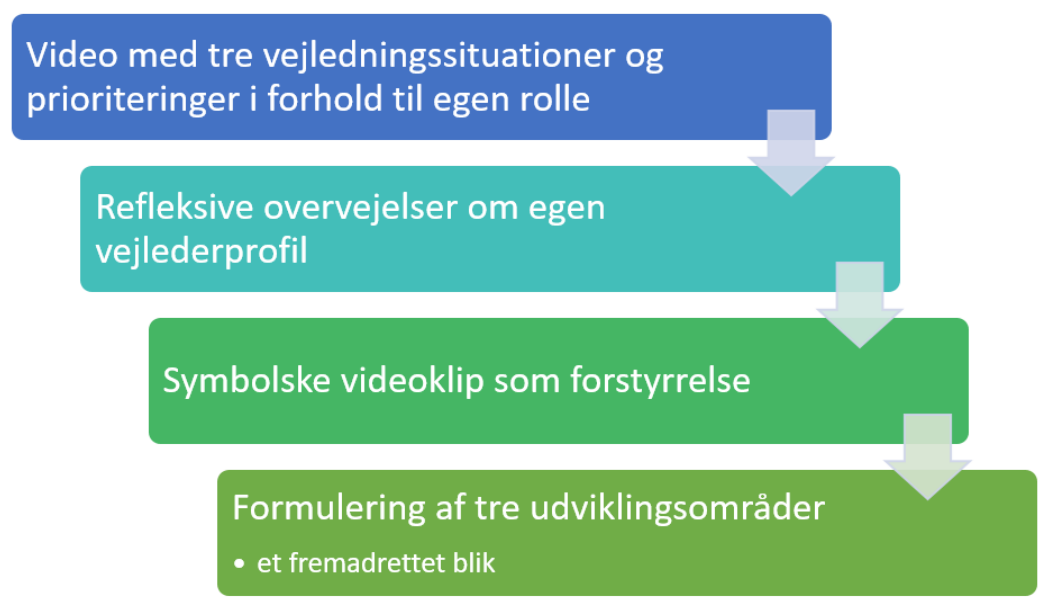

Figur 1. Simulationsprogrammets 4 elementer 
Indledningsvis er det antaget, at der skal forstyrrelser til, for at en klinisk vejleder kan bevæge sig fra 1. til 2. ordens refleksion. En forstyrrelse skal i denne kontekst ikke forstås som noget, der enten er positivt eller negativt, men mere som noget, der vækker den kliniske vejleders opmærksomhed. En forskel, der gør en forskel, i forhold til at reflektere, f.eks. information, der bryder med den forestilling eller de antagelser, som den kliniske vejleder på forhånd har (Bateson, 1991). I programmet er det forsøgt at skabe anledninger til forstyrrelser, som intenderet skulle give anledning til at se nye eller andre perspektiver på den enkeltes rolle som klinisk vejleder.

\section{Den metodiske tilgang}

Udgangspunktet for følgeforskningen har været en abduktiv forskningstilgang. Til at belyse følgeforskningens hypoteser er anvendt metodetriangulering, da der dels via spørgeskema blev set på konkrete vurderinger af simulationsprogrammet og processen, og yderlig via interviews blev undersgøt de kliniske vejlederes oplevelser af processen. Når der anvendes "mixed methods", kan problemfeltet belyses fra flere forskellige vinkler, og begrænsninger ved en enkelt metode mindskes. Derudover kan kvantitative fund uddybes gennem kvalitativ udforskning, hvorved validiteten styrkes (Polit \& Beck, 2018).

Spørgeskema blev anvendt til at få konkrete vurderinger og korte kommentarer i forhold til forskellige elementer i simulationsprogrammet og processen. Spørgsmålene omhandlede blandt andet: teknisk brugervenlighed, logikken i programmets opbygning, briefingen og debriefingen. Derudover blev der spurgt til hvad der i programmet gav anledning til refleksion, og ligeledes en vurdering af de enkelte dele i programmet. Spørgeskemaet var udformet, således at deltagerne skulle svare henholdsvis på en skala fra "I meget høj grad" til "slet ikke", samt åbne spørgsmål. Derudover var der ved hver kategori mulighed for at afgive øvrige kommentarer.

Spørgeskemaundersøgelsen blev på alle holdene lagt i forlængelse af simulationsprocessen, da der var fokus på at få deres umiddelbare refleksioner og vurderinger, mens oplevelserne stadig var friske i hukommelsen.

Indsamlingen, bearbejdningen og tolkningen af data, samt selve undervisningen blev alt sammen udført af de samme personer, hvilket kan have bidraget til en bias. Ved introduktionen til spørgeskemaet blev der brugt tid på at forklare, hvad det skulle bruges til. Ligeledes at det var vigtigt, at de svarede ærligt og ikke for at "please".

For at styrke validiteten af spørgeskemaundersøgelsen blev der suppleret med fokusgruppeinterview. Dette for dels at få uddybet og nuanceret de kliniske vejlederes oplevelser af forløbet, deres læreproces og refleksion. Dels for at tydeliggøre fundene i spørgeskemaundersøgelsen og eventuelle sammenhænge imellem dem. Den videnskabsteoretiske retning under fokusgruppeinterviewene var fænomenologiskhermeneutisk. (Birkler, 2005).

Der blev afholdt fokusgruppeinterviews med kliniske vejledere på tre forskellige moduler i hhv Århus og Viborg fra september - november 2016. Fokus for interviewene var baseret på de hypoteser, der ønskedes belyst, samt data fra de allerede indsamlede spørgeskemaundersøgelser. Den åbne interviewstil var valgt, idet det ville give informanterne mulighed for at lade sig inspirere af hinanden og udvikle svarene i samspillet. På den måde ville et svar kunne medvirke til refleksion hos en anden, hvilket ville muliggøre en synergi i gruppen og kunne give mere nuancerede svar (Halkier, 2008; Præstegaard, 2012). Derved anvendes gruppedeltagernes forskelligehed som middel til at producere data. En ulempe ved fokusgruppeinterviews kan være de uhensigtsmæssige gruppe effekter der kan forekomme, når det er den sociale interaktion, der er kilden til data (Halkier, 2008). En fokusgruppes produktion af viden afhænger af deltagernes sociale interaktion med hinanden. De må ikke være alt for homogene, ej heller alt for heterogene (Halkier, 2008). 
På de 3 moduler deltog henholdsvis 18, 21 samt 20 deltagere. Deltagerne var homogene på den måde, at de alle skulle være eller allerede var kliniske vejledere, og havde deltaget i simulationsprocessen. De var heterogene på den måde, at de kom fra forskellige sundhedsfaglige professioner og forskellige arbejdsfelter; så som somatisk hospital, psykiatrisk hospital, plejehjem $\mathrm{mm}$. De var endvidere heterogene ud fra deres forskellige erfaringer dels som professionsudøvere og dels som kliniske vejledere.

Alle deltagerne på holdene blev adspurgt om deltagelse i fokusgruppeinterview og udfra tilkendegivelse blev enkelte direkte adspurgt for at skabe heterogenitet i grupperne i forhold til professioner og erfaring. I alt 13 gav skriftligt tilsagn med informeret samtykke. Informanterne fordelte sig som skitseret i figur 2.

\begin{tabular}{||l|l|l||}
\hline Fokusgruppe 1 & 4 informanter & Sygeplejersker fra såvel hospital, kommune og psykiatri \\
\hline Fokus gruppe 2 & 4 informanter & Sygeplejersker fra hospital, kommune og hospice \\
\hline Fokusgruppe 3 & 5 informanter & $\begin{array}{l}\text { Sygeplejersker, sundhedsplejerske og fysioterapeuter fra hospital } \\
\text { og kommune }\end{array}$ \\
\hline
\end{tabular}

Figur 2. Fordeling af informanter til fokusgruppe interview

Der var under fokusgruppeinterviewene en bevidsthed fra interviewer om, at være åben, undersøgende og lyttende til de udsagn, som de kliniske vejledere kom med for at fă et nuanceret billede af deres oplevelser. Hvert interview havde en varighed af 45-60 minutter og var baseret på en semistruktureret interviewguide. I arbejdet med interviewene og efterarbejdet med transkripering og meningskondensering (Kvale \& Brinkmann, 2014) blev der for at bevare objektivitet byttet rundt, således at interviewer ikke arbejdede på eget interview. Den umiddelbare meningskondensering blev efterfølgende drøftet i forskningsteamet.

Den meningskondenserende tilgang har skabt overblik og identificeret betydningsenheder. Betydningsenhederne er de væsentlige temaer, som interviewpersonerne har kredset om i de tre interviews. Ud fra de identificerferede temaer er udvalgte temaer belyst i artiklen.

\section{Teoretisk perspektiv}

Grundlæggende har der i følgeforskningsprojektet været en forståelse af refleksion med udgangspunkt i Wacherhausen (2008). Derudover er der i artiklen arbejdet med teori på baggrund af de opståede mønstre for at skabe en dybere og mere nuanceret forståelse af resultaterne.

Ifølge Wacherhausen (2008) defineres refleksion som "en bevidst, omhyggelig og tidskrævende form for tænkning, som er karakteriseret ved en kritisk-konstruktiv spørgende og svarsøgende holdning." (Wacherhausen, 2008, s. 14). Centralt i denne definition pointerer Wackerhausen, at refleksionen er afhængighed af tid, ressourcer og vilje (Wacherhausen, 2008).

I data fra følgeforskningen ses det, at mulighederne for refleksion, og især 2. ordens refleksion, afhænger af, hvordan koblingen mellem praksis - teori - praksis sker. At kunne lave denne kobling er krævende. Det kræver fastholdelse, opmærksomhed og ikke mindst evne til selvrefleksion, og ifølge Wacherhausen (2008) kræver det at indtræde i et "fremmed landskab"; det vil sige at komme ud af sin komfort zone:

\footnotetext{
"Men at iværksætte og muliggøre 2. ordensrefleksion kræver ressourcer, som sædvanen sjældent (hvis overhovedet) er i tilstrækkelig besiddelse af. Sædvanen og etableret handlingsbåren kundskab har ressourcerne nødvendige for 1 . ordensrefleksion, men har
} 
sjælden ressourcerne - og motivationen - til at udfordre sig selv, til at udføre 2. ordensrefleksion." (Wacherhausen, 2008, s. 18)

Wacherhausen (2008) skelner mellem refleksion af 1. orden, som er en problemløsende refleksion, hvor der reflekteres over den netop overståede handling (f.eks. vejledning), og refleksion af 2. orden, hvilket er karakteriseret ved en refleksion over refleksionen af 1. orden. Refleksion af 2. orden går således dybere i forhold til at sætte fokus på præmisserne bag refleksionen af 1. orden. Dette kan være refleksion over, hvilke holdninger, værdier og grundantagelser, der ligger til grund for refleksionen (Wacherhausen, 2008). Refleksionen af 2. orden kan sammenlignes med det som Mezirow (1991) kalder kritisk selvrefleksion, hvilket kræver en afstand til selve handlingen.

Når der arbejdes med refleksion, og særligt 2. ordens refleksionen, så er det fordi at netop disse refleksioner er centrale, når det gælder om at få blik for ens egen rolle og fag-professionelle identitet, og det som denne identitet bygger på. At skabe en bevidst forholden sig til denne, giver muligheden for at vurdere hensigtsmæssigheden af de skemaer, som den enkelte har opbygget. Fra et teoretisk perspektiv vil der, ifølge Illeris (2015), som en naturlig del af læreprocessen kunne opstå frustration og måske endda modstand i en sådan sammenhæng, idet der kan skabes akkommodative eller sågar transformative læreprocesser. Disse læringstyper involverer en nedbrydning, omstrukturering og rekonstruktion af den enkeltes mentale skemaer, hvilket er en energikrævende proces.

\section{Aristoteles' videnformer}

For sundhedsprofessionelle er det at handle i praksis typisk en kompleks affære. Yderligere kompleks bliver det, når man skal lære at agere i rollen som klinisk vejleder. Det er komplekst at skulle forholde sig til en patient samtidig med, at man har en studerende eller kollega med, hvis læring man skal facilitere i situationen. Det stiller krav til det professionelle skøn, hvilket er centralt at udvikle som klinisk vejleder.

Udvikling af et professionelt skøn og sikringen af en større selvrefleksion og handlekompetence som klinisk vejleder, kan kobles ind i de tre vidensformer: episteme, techne og phronesis, som først formuleret af Aristoteles (Jensen \& Johnsen, 2010).

* Episteme - den videnskabelig viden, det teoretiske.

* Techne - den håndværksmæssige kunnen, eller tekniske 'know-how'

* Phronesis - den praktisk visdom eller viden om, hvad der skal til, når livet imellem mennesker skal lykkes. Man kunne også kalde det moralsk tæft og situationsfornemmelse.

At udvikle et professionelt skøn og en praksis, hvor fokus er på selvrefleksion og refleksion over praksis, kræver en integrering af de forskellige vidensformer. At kunne håndtere den kompleksitet, der er i praksis, gør at man, som klinisk vejleder, er nødt til at kunne forene videnskabelig viden, håndværksmæssige kunnen med dømmekraft, praktiske visdom og handlekraft, der er kendetegnende for phronesis. Især det at besidde phronesis er, ifølge Jensen og Johnsen (2010), centralt i forhold til at udvikle det professionelle skøn. Det omhandler en forståelse af både en selv, men også af andre mennesker samt det at kunne reflektere kritisk og afvige fra regler, når den phronesiske-viden sætter en anden retning (Jensen \& Johnsen, 2010). 


\section{Aristoteles' og Wackerhausens kobling til projektet}

I data fra projektet synes der at være indikatorer for, at de kliniske vejledere, med udgangspunkt i Aristoteles' vidensformer, får skabt en mulighed for at udvikle det fag-professionelle skøn. Gennem simulationsprocessen skabes en mulighed for integration af de tre nævnte vidensformer via teoretiske perspektiver for refleksion og vejledning, en mulighed for spejle sig i en teknisk 'know-how' og håndværksmæssig kunnen samt muligheden for at sætte den praktiske visdom i spil i de kritiske refleksioner i debriefingen.

Den kritiske refleksions kobling af vidensformerne er ligeledes noget Wacherhausen er optaget af. Hvor Aristoteles taler om episteme, techne og phronesis, taler Wacherhausen om det skolastiske og nonskolastisk paradigme, og om et behov for at forene disse gennem refleksion og dialog, således at praksis udvikles. Han skriver:

\footnotetext{
"Alt dette vil imidlertid fordre en opløsning af såvel det skolastiske som non-skolastiske paradigmes selvtilstrækkelighed og en frugtbar syntese af de indsigter og muligheder, som findes i begge paradigmer." [...] "Det kræver en retænkning af såvel teori som praksis. Og en anerkendelse af at erfaring uden refleksion er blind, og refleksion uden erfaring er tom." (Wacherhausen, 2008, s. 19)
}

\section{Vikarierende erfaringer, som grundlag for udviklingen}

Ud fra et andet teoretisk perspektiv er det tydeligt, at et af fundamenterne som skaber muligheden for at udvikle de kliniske vejlederes dømmekraft, er vikarierende erfaringer eller modellæring, som den amerikanske psykolog Bandura (2012) taler om.

Med udgangspunkt i et socialt læringsperspektiv handler modellæring, ifølge Bandura, om hvordan mennesket lærer gennem observation af andres adfærd, samt konsekvenserne af denne adfærd (Bandura, 2012; Løw, 2017)

Ifølge Bandura leder mennesker efter kompetente rollemodeller, der besidder de evner, de selv stræber efter (Bandura, 2012). Med udgangspunkt i Banduras teori kan modellæring, ifølge Løw, ligeledes ske uden at vejledere foretager vejlednings-handlinger (Løw, 2017), hvilket kan antyde, at vejledning kan læres ved at observere videooptagelser af vejledning.

Ved at observere mennesker som én selv, vil man ifølge Bandura (2012), få en større tiltro til, at man kan håndtere lignende opgaver og få succes. Modellæring kan bidrage til at skabe noget nyt afhængig af mangfoldigheden af modeladfærden, som den enkelte får adgang til i den pågældende sammenhæng (Løw, 2017). I projektet får de kliniske vejledere adgang til flere forskellige perspektiver, samt fælles refleksion over disse, hvilket må vurderes som en mulighed for modellæring.

Donald Schön bruger i denne sammenhæng, ifølge Løw, begreberne refleksiv imitation, imitativ rekonstruktion og selektiv konstruktion, til at beskrive det de lærende (kliniske vejledere) gør, når de tolker på de handlinger de har set "modellen" lave og på baggrund af dette, drager egne konklusioner (Løw, 2017).

I simulationsprocessen skabes der, igennem en kobling mellem handling i form af vikarierende erfaringer via video og refleksion i debriefingen, en mulighed for, at der udvikles et nyt handleberedskab, der kan kvalificere fundamentet i det professionelle skøn. 


\section{Analyse og fortolkning af resultater}

Gennem bearbejdningen af datamaterialet er det blevet tydeligt, at teknologien bidrager med en helt overordnet rammesætning for skabelsen af refleksion. Indledningsvis vil teknologiens bidrag derfor bliver belyst, hvorefter de øvrige temaer vil blive kortlagt, analyseret og diskuteret.

\section{Teknologiens bidrag - et udgangspunkt for refleksion}

I gennemgangen af simulationsprogrammet oplever de kliniske vejledere, at det er en konkret opgave, som de skal udføre. Dette kan ses i modsætning til, at de i en klasseundervisning kan koble fra undervejs; være mindre til stede.

\footnotetext{
"Man kan ikke koble fra, man kommer ikke videre, før du selv kobler dig på og fortsætter, man kan ikke lave andet". (Informant H)
}

De bliver "fastholdt" og tvunget til at forholde sig til sig selv som kliniske vejledere. Teknologien er med til at give en mere struktureret og styret vej igennem simulationsprocessen, som citatet ovenfor også indikerer.

I såvel interviewene som i spørgeskemaet bliver de kliniske vejledere spurgt til, hvordan anvendelse af teknologi bidrog til opgaven. Overordnet set udtrykker de, at det giver en anden måde at lære på, som er et godt supplement til den øvrige undervisning. De udtrykker, at med teknologi bliver det en individuel og en mere personlig proces. Det blev deres egne svar og refleksioner, de arbejdede med. Dette sætter de i modsætning til undervisning på klassen, hvor de bliver påvirket af andres sprogliggjorte refleksioner.

Teknologien bidrog ligeledes med, at de kunne arbejde i deres eget tempo, men alligevel i en ledet proces. Flere udtrykker, at det at gennemføre programmet, gav dem mulighed for at fordybe sig, hvilket de oplevede som meget positivt.

Et væsentlig teknologisk bidrag er det visuelle. Mange af de kliniske vejledere udtrykker, at det at se vejledningsvideoer og de symbolske videoklip har stor betydning. I datamaterialet kan det udledes, at de husker det visuelle bedre modsat det at læse en tekst, ligeledes antydes det flere steder, at kombination af det visuelle og tekstbaserede giver en bedre effekt.

\footnotetext{
"En ting er at læse det, men når man så ser det visuelt, og der kommer noget video på, det gav invertfald for mig noget andet, fordi det var så tydeligt". (Informant J)

"Man husker det bedre. [...] at få det kombineret, det har bare en bedre effekt". (Informant K)
}

Teknologien bidrager ligeledes til, at de kliniske vejledere kan gå tilbage i programmet og at de kan læse, se og gense dele af forløbet, hvilket giver dem noget mere og nogle gange noget andet.

\footnotetext{
"Det er det der er rigtig fedt ved at bruge IT, at man kan se det igen og igen og igen". (Informant G)

"Her kommer der ligesom noget udefra [teknologi], der forstyrrer det [refleksionen], der sætter nogle andre tanker i gang". (Informant P)
}

Selvom de kliniske vejledere er positive omkring anvendelse af teknologi og simulation i undervisningen, så betoner de alligevel, at det er væsentligt, at den nuværende undervisningsform bevares. Simulationsprocessen har været spændende og skabt en bevidsthed om deres ståsted som 
vejledere. Der er ingen tvivl om, at denne form for læring har givet dem noget andet end traditionel undervisning.

\footnotetext{
"Jeg synes det var rigtig godt. [...] Jeg synes det har givet noget som vi ikke har fået i undervisningen. Vi har fået rigtig mange gode ting i undervisningen, men det her det har sat et andet perspektiv på." (Informant A)
}

\section{Simulation som et spejl - "at spejle sig"}

Simulationsprogrammet indledes af en række vejledningsvideoer. I programmet vises tre forskellige tilgange til vejledning, først en meget instruerende (mesterlære) tilgang til vejledning, derefter en coachende tilgang og til sidst en tilgang baseret på en refleksionsmodel kaldet de tre H'er (Bagger \& Schultz, 2014, s. 51-55). Vejledningsvideo 1 blev i første omgang oplevet som overdrevet og karikeret, men igangsatte samtidigt mange refleksioner, hvorfor den blev bibeholdt i programmet, da dette blev tilpasset. Antagelsen var, at denne og de andre vejledningsvideoer, ville give mulighed for spejling, men også mulighed for nye perspektiver, der ville kunne skabe refleksion.

Helt overordnet ses det i datamaterialet, at det har en vis effekt på de kliniske vejledere at se videooptagelser af forskellige vejledningstyper. Via programmet har de fået et visuelt bekendtskab med, hvordan vejledning konkret kan foregå. I spørgeskemaundersøgelserne udtrykker de kliniske vejledere sig generelt positivt med kommentarer som "realistiske", "gav god forståelse" og "læringsrige". Nogle var dog mere kritiske og udtrykte, at især én af vejlednings videoerne var meget "overspillet", ligeledes var en anden vejledningsvideo ikke i tråd med de 2 øvrige, hvilket skabte frustration. Enkelte udtrykte, at videoerne ikke matchede deres praksiskontekst, og dermed kunne være svære at forholde sig til. Grundlæggende er det de samme svar, der viser sig i analysen af interviewene.

Yderlig viser analysen, at selvom der i den traditionelle undervisning i klasserummet undervises i vejledningsteori og de kliniske vejledere øver vejledningsfærdigheder, så giver videooptagelser med eksempler på, hvordan vejledning konkret kan foregå, noget mere end det de kliniske vejledere opnår i undervisningslokalet; noget mere praksisnært og anvendelsesrelateret. Det ses af flere udtalelser:

"Det er noget af det vi har manglet. Vi har meget teori, men hvordan anvender vi det sådan helt i praksis. Det synes jeg var rigtig godt." (Informant E)

Det praksisnære og anvendelsesorienterede er endvidere medvirkende til, at de kliniske vejledere relaterer sig til vejledningsvideoerne og på baggrund heraf vurderer, hvorvidt den rolle, som vejlederen i vejledningsvideoen tager, er en rolle, som de også selv vil kunne tage som vejleder. Det medvirker til at de kliniske vejledere spejler sig i vejledningsvideoerne.

\section{"[...] man ku ligesom bedre se sig selv i de forskellige situationer..., når man så så det på videoer..." (Informant I)}

Spejling set i relation til Bandura (2012) og Løw (2017), kan tolkes ud fra at vejlederen ses som model, og de kliniske vejledere, bliver de lærende, som lærer af eller spejler sig i den adfærd, de observerer på videoen; modellæring. Vejledningsvideoerne kommer til at fungere som en slags visuelle rollemodeller, som de kliniske vejledere kan spejle sig i. Den enkelte kliniske vejleders potentiale og motivation bliver væsentlig for at kunne skabe spejlingen.

\section{At spejle sig i noget konkret giver sikkerhed og udviklingsmulighed}

Flere udtrykker, at det er nemmere at spejle sig i noget konkret, og det giver dem en sikkerhed i forhold til nuværende ståsted som vejleder. Der udtrykkes endvidere, at en faglig sikkerhed som vejleder er væsentlig i modsætning til en "utryg vejleder", idet utryghed kan have en afsmittende effekt. Som 
Bandura (2012) beskriver det, vil der ved observation af ligesindede skabes en selvopfattelse, der bygger tiltro til egne evner og succes. Informanterne giver udtryk for betydningen af en øget faglig sikkerhed som vejleder, men udtrykker også en udviklingsmulighed.

\footnotetext{
"Jeg synes det bidrager meget til at være sikker på sin rolle som vejleder [...] De studerende har brug for en sikkerhed og ikke en utryg vejleder." (Informant B)
}

At se videooptagelser giver mulighed for udvikling og ikke blot at forholde sig til egen vejlederrolle, men også til egne rammer for vejledning. Den spejling, der foregår, skaber en refleksion bl.a. om de rammer der er i praksis i forhold til at udøve vejledning.

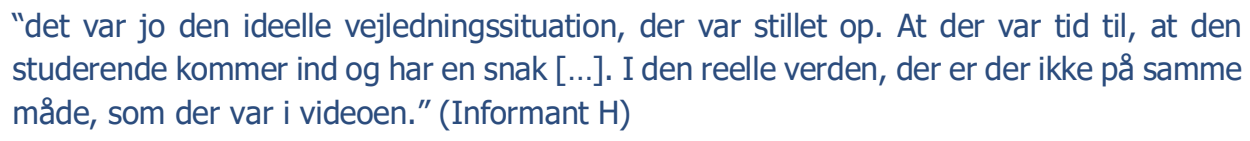

Citatet herover kan også antyde en udfordring i forhold til at transformere situationen til andre kontekster. Trods den måske ideelle fremstilling om vejledning, giver det imidlertid anledning til overvejelser omkring, hvorvidt det kan gavne refleksionen, at der ikke i praksis er den ideelle kontekst for vejledning. Dog er det væsentligt, at denne erkendelse opnås og ikke stiller en som en dårligere vejleder.

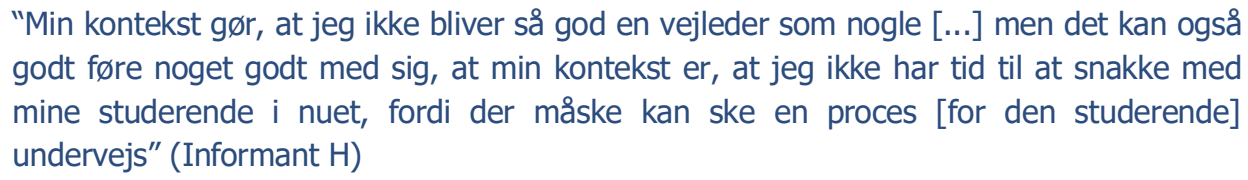

Yderligere spiller rammerne i praksis også ind i forhold til at kunne spejle sig i kollegaer. Når arbejdspladserne ikke nødvendigvis giver denne mulighed, kan det synes væsentlig, hvordan vejledning præsenteres, og hvordan det efterfølgende reflekteres.

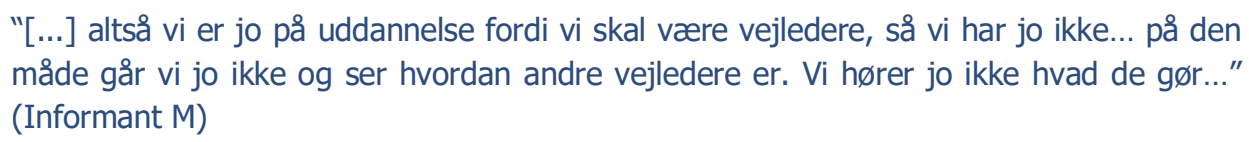

Teoretisk viser det sig, at der er forskellige måder at spejle sig på. Der er den direkte spejling; "sådan kan jeg gøre" eller "sådan gør jeg", og her skabes refleksion af 1. orden (Wacherhausen, 2008). Men der er også kliniske vejledere, som spejler sig i videoerne, og som på baggrund af disse spejlinger overvejer, hvilke værdier de har som baggrund for deres handlinger, og her skabes refleksion af 2. orden.

\section{Vejledningsvideoerne som anledning til frustration}

Ligesom vejledningsvideoerne fungerede som spejl for, hvorledes de kliniske vejledere ønskede at vejlede, så gav de også anledning til frustration. Frustration på den måde, at de kliniske vejledere også spejlede sig i forhold til, hvordan de ikke ønskede at vejlede. I interviewene ses, at det især er vejledningsvideoen præget af en mesterlære tilgang, hvor det er vejlederen, som ved bedst og anses som guru (Bagger \& Schultz, 2014; Bjørndal, 2011; Handal, 2007), der giver anledning til frustration. Denne video blev oplevet som karikeret og opstillet med et negativt indtryk af vejlederen. Oplevelsen af videoen gav for mange af de kliniske vejledere anledning til refleksion over, hvilke værdier der var væsentlige i et mesterlære perspektiv.

"[...] jeg synes jo godt, at man kan lave mesterlære på en helt anden måde. Og stadigvæk høre den studerende og lad den studerende komme på banen. Så det frustrerede mig lidt. Jeg synes ikke den video, den var tro mod mesterlæren." (Informant I) 


\section{Opsamling}

Analysen viser, at de kliniske vejledere i høj grad spejlede sig i vejledningsvideoerne, idet den praksisnære kontekst i videoerne gav dem mulighed for en visuel præsentation af konkrete og praksisnære vejledningssituationer. En interessant betragtning er, at der bliver givet udtryk for mangel på praksisfærdigheder i vejledning. På det ene hold har der været arbejdet med konkrete vejledningsøvelser som en del af undervisningen, men det at se vejledningsvideoerne giver dem noget mere eller andet; noget som de ikke oplever, at de får i undervisningen. Blandt andet gav det en høj grad af sikkerhed, både i forhold til eget ståsted, men også i forhold til egen udvikling.

I forhold til refleksion, gav vejledningsvideoerne ikke kun anledning til 1. ordens refleksion i form af bl.a. transfer til en nær kontekst jf. Wahlgren og Aarkrog (2012), men der foregik ligeledes 2. ordens refleksion, hvilket kom til udtryk gennem den udtrykte frustration og provokation, som vejledningsvideoerne gav anledning til. Dette skabte mulighed for at sætte fokus på egne værdier og holdninger, hvilket flere opnåede gennem påvirkningerne fra vejledningsvideoerne og deres efterfølgende reflektioner.

\section{Forstyrrelser - påvirker de refleksionen?}

I programmet præsenteres de kliniske vejledere for en række korte klip af bl.a. politi (magt); præst (prædiken); damptromle ("kører over"); etc., som symbolske eksempler på adfærd. I designet og testen af programmet var perspektivet, at de symbolske videoklip gav anledning til at se nye aspekter af rollen som vejleder, hvilket skabte en antagelse om, at det ligeledes ville være tilfældet hos de kliniske vejledere.

\section{Forstyrrelser er svært}

Der var stor forskel på, hvordan de kliniske vejledere oplevede de symbolske videoklip. Nogle oplevede, at de symbolske videoklip ikke handlede om vejledning, at konteksten blev fjern (Wahlgren \& Aarkrog, 2012) og abstraktionsniveauet blev for højt, hvilket udfordrede opnåelsen af 2. ordens refleksion. En klinisk vejleder udtrykker:

\footnotetext{
"Forstod overhovedet ikke videoerne... gav slet ikke mening for mig, hvorfor vi skulle se dem og da nogle kun var 1-2 sekunder, nåede jeg ikke at se hvad jeg skulle se efter... forstyrrelser, ja, men ikke på en god måde" (spørgeskema undersøgelse, Aarhus)
}

Fra spørgeskemaundersøgelser ses også kommentarer som "Først forstyrrende, men så gav de grundlag for refleksion" (spørgeskemaundersøgelse, Viborg). I denne kommentarer ligger også en anden problematik, nemlig forståelsen af begrebet "forstyrrelse", som her forbindes med noget uhensigtsmæssigt. Forstyrrelse opleves hos de kliniske vejledere ikke som noget, der kan igangsætte refleksion. Der var kliniske vejledere som forventede, at forstyrrelser var noget, som skulle vende fuldstændig op og ned på deres forståelse af "verden". De forventede at blive forstyrret, men uden at de oplevede, at de blev det.

Forventningen kan uhensigtsmæssigt være forekommet i introduktionen (briefingen), hvor det blev introduceret, at der ville komme forstyrrelser undervejs i simulationsprogrammet.

\footnotetext{
"Jeg havde forventet at præsten faldt ned af prædike stolen, at politiet tabte fangeren. Men det skete ikke. Hvad var det så at jeg skulle have lagt mærke til?" (Informant H)
}

At bruge begrebet forstyrrelse har således ikke været uproblematisk. Det har givet anledning til forvirringer og misforståelser, som har været nødvendige at uddybe, afklare og udvikle undervejs. 


\section{Fra umiddelbare forvirring til refleksiv respons}

De symbolske videoklip giver for nogle anledning til refleksion, men for de fleste kræver det, som en informant beskriver nedenfor, at de ses flere gange.

"Der var også de der 7 videoer [...] først gang jeg så dem, tænkte hmmm det var da noget helt andet og så jeg dem en gang til, og så det der med... det der så kom op i mig i anden runde, det synes jeg var helt vildt spændende, [...] så kunne jeg lige pludselig sætte nogle ord på" (Informant I)

Det at være nødt til at se videoklippene flere gange, tegnede sig generelt. Ved første øjekast kan videoklippene virke forvirrende og den kliniske vejleder får, hvad man i en innovationskontekst kalder benspænd. Begrebet benspænd forstås i denne kontekst som: en uventet og tilsyneladende mærkelig hindring, der kastes ind og kan give et indspark f.eks. i en refleksionsproces (Amabile, 1996; Onarheim \& Wiltschnig, 2010).

I situationen kan den enkelte blive slået ud af kurs, men ved at gense de symbolske videoklip, opstår der nye perspektiver på rollen som vejleder.

"Jeg skulle også tænke meget over det før at jeg faktisk kom til den der refleksion i at skulle trække nogle delelementer ud, for [...] og kunne forstå det. For det giver jo mening i videoen" (Informant B)

Pointen med gentagelserne præciseres meget konkret i det en informant udtrykker:

\section{"[...] hvis man begynder at se det igennem flere gange, så får man ikke den umiddelbare} respons, men den refleksive respons" (Informant E)

Som Mezirow (1991) samt som citatet ovenfor også udtrykker det, så er det når der dvæles ved noget, og man ikke er i en situation som kræver handling her og nu, at mulighederne for kritisk refleksion skabes, og det skaber simulationsprogrammet rum til.

\section{Indsigt og dialog, som faciliterende for skabelsen af refleksion}

De symbolske videoklip gav de kliniske vejledere mange forskelligartede oplevelser. Både hvorvidt de gav anledning til refleksion, men ligeledes i forhold til, hvad de rent faktisk så, og hvilken værdi de tillagde dem. Hvor nogle så dirigenten som dominerende og styrende, oplevede andre ham som energisk, smilende og imødekommende, og endnu en lagde mærke til detaljen "exit skiltet" i baggrunden.

\footnotetext{
"Vi brugte jo faktiske meget tid i frokostpausen på, at snakke om, hvad man havde fået ud af at se de der videoer. Det var meget forskelligt hvad man havde lagt i det. Det tror jeg faktisk godt kunne give noget læringsmæssigt" (Informant D)
}

Citatet illustrerer både pointen med de forskelligartede oplevelser, men pointerer ligeledes læringsværdien i efterfølgende at tale om dem. Ved at den kliniske vejleder oplever andre kliniske vejledere beskriver deres refleksioner, faciliteres deres egen refleksion. Derudover kan det også give dem mulighed for, at få blik på deres egne blinde pletter og få bevidstgjort deres egne værdier og grundlæggende antagelser (Scheibel 2010). De får derved også muligheden for at gå fra 1. til 2. ordens refleksioner igennem hhv. de formelle og uformelle dialoger efterfølgende.

"Jeg synes jo det var interessant i debriefingen vi havde i grupper, at vi havde set helt andre ting, at vi blev påvirket forskelligt af de sessioner. [...] Og man bliver forstyrret forskelligt." (Informant M) 
For mange af de kliniske vejledere er det først i bilen på vej hjem, i frokostpausen eller den mere formelle debriefing, når de bliver spurgt yderligere ind til deres oplevelser og overvejelser, at de får mulighed for 2. ordens refleksioner. De symbolske videoklip og vejledningsvideoerne giver anledning til forstyrrelser og refleksion, men forstyrrelser og refleksion skabes også i dialogen om udviklingsspørgsmålene, som de kliniske vejledere skal beskrive til sidst i programmet.

\section{"det var rigtig spændende at høre, hvad de andre havde sagt af udviklingsområder. Hvad de skulle udvikle på. [...] Det skabte egen refleksion, hvad tænker man lige selv om det" (Informant F)}

Debriefing er en vigtig del af simulationsprocessen, og giver mulighed for en guidet proces med refleksion og dialog om processen (Jones et al., 2015). Dermed făr de kliniske vejledere mulighed for, at italesætte det de har set og komme et lag dybere i forhold til egne værdier og antagelser. Debriefingen skaber rum til dialog, hvor selvrefleksion bliver faciliteret. Debriefing giver de kliniske vejledere mulighed for at eksperimentere og lære i en tryg kontekst, hvilket er en af styrkerne.

\section{Opsamling}

Forstyrrelser virker og kan give anledning til refleksion, men det kan ikke påtvinges, og alt efter hvordan forstyrrelserne opleves, og hvor abstrakte de er, vil de have større eller mindre effekt. De symbolske videoklip kan, ifølge datamaterialet, give anledning til både 1. og 2. ordens refleksion. Her ses det ligeledes, at debriefingen kan være faciliterende i forhold til, at de kliniske vejledere kan reflektere af både 1. og 2. orden. Det er ikke kun de symbolske videoklip som skaber forstyrrelser, der er også som tidligere beskrevet vejledningsvideoerne. Hvor forstyrrelserne i de symbolske videoklip kan være svære at koble sig på, oplever de kliniske vejledere modsat, at det ikke er svært at koble sig på forstyrrelserne, som skabes, når de ser vejledningsvideoerne. De symbolske videoklip komplicerer transfer og kræver et andet abstraktionsniveau. Data viser, at når 2. ordens refleksionen lykkedes for den kliniske vejleder, så skabes der mulighed for at udvikle egen praksis.

\section{Forskellige refleksionsformer}

I datamaterialet er det tydeligt at de kliniske vejledere reflekterer på forskellige måder, og at der er forskel på, hvor erfarne de er i at reflektere. Nogle skaber mening ved at matche videoerne med teori. Andre har fokus på egen kontekst og kan have svært ved at lave transfer fra videoerne til egen praksis. Andre igen er praktisk teoretisk reflekterede, og forstår at bringe begge perspektiver i spil - hvilket resulterer i 2. ordens refleksion. På baggrund af datamaterialet uddybes og underbygges dette i følgende tre refleksionsformer.

\section{Teoretisk akademisk refleksion $\rightarrow$ skal matche teori}

For en del af de kliniske vejledere var refleksionerne bundet op på at skulle matche den teori, de havde lært i undervisningen. Flere kliniske vejledere gav udtryk for frustration, når de ikke oplevede en klar teoretisk kategorisering, som kunne definere rigtigt og forkert, og de efterspurgte en tydelig teoretisk vejledningsprofil som resultat af simulationsprogrammet.

Simulationsprogrammet definerer ikke et rigtig eller forkert svar i forhold til vejledning, men mere en anledning til at reflektere over sig selv som vejleder, og det der ligger bag, det man gør.

\section{Praktisk kontekst refleksion $\rightarrow$ skal matche kontekst}

For andre kliniske vejledere var det i højere grad konteksten og deres praksis, som styrede refleksionen, hvilket kunne skabe en barriere i forhold til at reflektere. 
"...de der forstyrrelses videoer, dem blev jeg egentlig ikke så forstyrret af [...] jeg kunne jo godt se, at de også vejledte på hver deres måde, som passede ind i den kontekst de nu en gang var i, og hvad der var optimalt i den kontekst de var, men jeg kan jo ikke på den måde tage det hele til mig og sige at det passer i den kontekst jeg skal vejlede i..."

(Informant D)

Det er tydeligt, at den kliniske vejleder her er opmærksom på sin kontekst, og det at overføre elementer fra en kontekst til en anden er ikke umiddelbart oplagt. I beskrivelsen af oplevelsen bliver det tydeligt, at der er sket en forstyrrelse. Spørgsmålet kan være, hvordan begrebet "forstyrrelse" er blevet forstået, idet videoerne har givet anledninger til refleksioner over, hvordan man ikke er vejleder. Umiddelbart viser data at refleksionen bliver på 1. ordens niveau, idet refleksionen over værdier og holdninger ikke skabes. Dog kan det ikke vurderes om det over tid har givet anledning til videre refleksion.

\title{
Praktisk - teoretisk refleksion $\rightarrow$ skal udvikle praksis
}

En tredje form for refleksion, som kan udledes af datamaterialet, er det der her kaldes en praktisk teoretisk refleksion, eller med Wacherhausens (2008) ord:

"... en frugtbar syntese af de indsigter og muligheder, som findes i begge paradigmer [det skolastiske og non-skolastiske paradigme]." (Wacherhausen, 2008, s. 19)

Her kombinerer de kliniske vejledere teori og praksis. Fokus bliver på at udvikle praksis, ved at se på "hvad gør jeg", "hvorfor gør jeg det" og "hvordan vil jeg gerne have det skal være ud fra den viden jeg har".

\begin{abstract}
"Den der refleksion jamen en ting er, hvad jeg gerne vil gøre så’n, men gør jeg så egentlig det. Fordi jeg kunne tydeligt se ud fra de her [vejledningstyper], jamen hvad for en, ville jeg helst ville vælge, hvis det var [...] men hvordan gør jeg så egentlig det, eller vil jeg bare gerne gøre det. Så det satte egentlig nogle rigtig fine tanker i gang om, hvordan gør du så egentlig i praksis." (Informant J)
\end{abstract}

Her får den kliniske vejleder sat fokus på dels det der gøres, dels det der tænkes gjort. Den kliniske vejleder er tydeligt selvreflekterede i forhold til, hvordan arbejdet udføres, og om hvorvidt det gøres, som den kliniske vejleder gerne vil gøre det.

En anden informant sætter fokus på nogle af de samme elementer:

\begin{abstract}
"... nu har vi set på at arrrh... det er nok vejledningstype 2 og 3 der er de rigtige, i hvert fald dem vi stiler imod, og jeg er helt klart også følelsesmæssigt [...] vi er vejledningstype 1 , og som jeg har ageret meget i, og hvor jeg også tænker, det er den der mesterlære eller ej [...] der hvor jeg står og der hvor jeg handler med de studerende, det går simpelthen så stærkt nogle gange øhhh og der kommer jeg til og tag over [...] Og vi bliver nødt til at reagere promte der..." (Informant K)
\end{abstract}

Citatet afspejler samtidig en refleksion over de præmisser, som informanten er underlagt i sin praksis med handletvang og travlhed som noget der har indflydelse på rollen som vejleder.

\section{Opsamling}

Forfatterne antager ikke, at 2. ordens refleksion er, hverken finere eller bedre end 1. ordens refleksion. De tjener hver sit formål. Hvor 1. ordens refleksion er en nødvendighed til at finde løsninger i en hverdag præget af drift og handletvang, ses 2. ordens refleksion som en mulighed for at komme bag om de præmisser, der styrer praksis og derved skabe udvikling. 
Med simulationsprocessen har ønsket været at give anledning til refleksion og i særdeleshed 2. ordens refleksion og skabe bevidsthed omkring de grundlæggende antagelser og værdier, der er styrende for de kliniske vejlederes ageren. At gennemgå simulationsprocessen væk fra egen praksis, i et rum uden handletvang giver de kliniske vejledere mulighed for at træde ud af en produktionslogik og over i en udviklingslogik, hvor der er tid, rum og afstand til at skabe selvrefleksion (Ellstrøm, 2012; Mezirow, 1998, 2012).

Som analysen af datamaterialet også illustrerer, så er bevægelsen fra 1. til 2. ordens refleksion kompleks og udfordrende for de kliniske vejledere, hvilket kommer til udtryk i de forskelligartede refleksionsformer identificeret. Sættes fokus på praksis-kontekst refleksion og den teoretiskakademiske refleksion, ses det at hhv. praksis og teori skaber barrierer i forhold til egen selvrefleksion. Selvrefleksion er udfordrende og kan igangsætte akkommodative og transformative læreprocesser, hvilket kræver energi og kun skabes, hvis den enkelte kan se en mening med eller et behov for udvikling (Illeris, 2013, 2015). Dette afspejler sig i den praktisk-teoretiske refleksion. Her har den kliniske vejleder en fleksibilitet og en åbenhed i forhold til selvrefleksion, og trækker på både teori og praksis med henblik på udvikling af egen praksis. Debriefingen kan virke faciliterende i forhold til at tydeliggøre meningen og behov for selvrefleksion, og er endvidere med til at udfordre barrierne.

Analysen viser imidlertid, at simulationsprocessen understøttet af teknologi bidrager til at facilitere denne bevægelse.

\section{Konklusion}

Det kan konkluderes, at der gennem en teknologisk understøttet simulationsproces kan skabes såvel 1. ordens som 2. ordens refleksion. Analyserne skitserer tre former for refleksion, hvoraf de to former fungerer som barrierer for 2. ordens refleksion og dermed bliver ved en 1. ordens refleksion. Det var i analysen overraskende, at transformationen fra simulationsprogram til de kliniske vejlederes egen praksis for nogle var svær, trods det at vejledningsvideoerne var praksisnære.

Teknologiens rolle i simulationsprocessen har skabt mulighed for at arbejde på et individuelt niveau og i eget tempo samt gentage efter behov. Anvendelse af teknologi skaber endvidere mulighed for visualisering og giver dermed anledning til en oplevelsesorienteret og spejlende tilgang til læring. Ligeledes viser det sig at forstyrrelser er nødvendige for at skabe 2. ordens refleksion, men at forstyrrelserne samtidig viser sig svært for de kliniske vejledere. Teknologien og den efterfølgende debriefinger kan være medvirkende til at understøtte skabelsen af 2. ordens refleksion, men at skabe forstyrrelser kan ikke umiddelbar påtvinges. Det vil kræve yderligere didaktiske overvejelser i forhold til at tilrettelægge forstyrrelser, hvor teknologi kan virke faciliterende. Dog kan teknologi være med til at sikre, at alle er aktive og deltagende.

Fremadrettet kan der være potentiale i, at de kliniske vejledere har gennemgået simulationsprogrammet hjemme for ikke at føle sig tidspresset samt give underviserene mulighed for at udnytte tiden i undervisning til at udfordre barrierer, facilitere 2. ordens refleksion og optimere udbyttet.

\section{Referencer}

Amabile, T. M. (1996). Creativity in Context. Hentet fra http://www.hbs.edu/faculty/Pages/item.aspx?num=268 Andersen, L. L. (2010, december). Laringsarenaer, simulering og refleksion i komunale konsulentforløb. Oplæg for Servicestyrelsen præsenteret ved København. København.

Bagger, C., \& Schultz, H. (2014). Vejledning af fagprofessionelle i klinisk praksis (1. udgave). København: Munksgaard.

Bandura, A. (2012). Self-efficacy (T. Havemann, Overs.). Foretagsomhedens poedagogik, 22(83), 16-35.

Bateson, G. (1991). And og natur: en nødvendig enhed. Kbh.: Rosinante/Munksgaard.

Birkler, J. (2005). Videnskabsteori (1. udgave). Munksgaard. 
Bjørndal, C. (2011). Rådgiver eller veileder? Forståelsen av direkte og indirekte hjelp. I K. Skagen (Red.), Kunnskap og handling i pedagogisk veiledning (2. Udgave, Bd. 2011, s. 189-209). Bergen: Fagbokforlaget.

Brøbecher, H., \& Mulbjerg, U. (2010). Klinisk vejledning og poedagogisk kompetence i professionsuddannelser (2 udgave). Kbh.: Munksgaard Danmark.

Conole, G. (2007). Describing learning activities -Tools and resources to guide practice. I H. Beetham \& R. Sharpe, Rethinking Pedagogy for a Digital Age: Designing and Delivering E-learning (s. 81-91). New York : London: Routledge.

Ellstrøm, P.-E. (2012). Læring i spændingsfeltet mellem produktionens og udviklingens logik. I K. Illeris (Red.), 49 tekster om lcering (s. 467-476). Frederiksberg: Samfundslitteratur.

Garrison, D. R., \& Vaughan, N. D. (2008). Blended learning in higher education: framework, principles, and guidelines (1st ed). San Francisco: Jossey-Bass.

Gynther, K. (2005). Blended learning: it og laering i et teoretisk og praktisk perspektiv(1. udg.). Kbh.: Unge Pædagoger.

Hachmann, R., \& Holmboe, P. (2014). Flipped learning - mere end bare video (2. udgave, 2. oplag). København: PRAXIS - Nyt Teknisk Forlag.

Hachmann, R., \& Holmboe, P. (2015). Flipped learning: flip med video (1. udgave). Odense SØ: PRAXIS - Nyt Teknisk Forlag.

Halkier, B. (2008). Fokusgrupper. Frederiksberg: Samfundslitteratur.

Handal, G. (2007). Veiledning i pedagogisk arbeid. I Tomas Krogsmark \& K. Åberg (Red.), Veilederen: guru eller kritisk venn? Bergen: Fagboklaget.

Illeris, K. (2013). Transformativ loering og identitet. Frederiksberg: Samfundslitteratur.

Illeris, K. (2015). Laering. Frederiksberg: Samfundslitteratur.

Jensen, T. K., \& Johnsen, T. J. (2010). Sundhedsfremme i teori og praksis: en lare-, debat-og brugsbog på grundlag af teori og praksisbeskrivelser (2. udgave). Århus: Philosophia.

Jones, F., Passos-Neto, C. E., \& Braghiroli, O. F. M. (2015). Simulation in Medical Education: Brief history and methodology. Principles and Practice of Clinical Research, 1(2). Hentet fra http://ppcr.org/journal/index.php/ppcrjournal/article/view/12

Kvale, S., \& Brinkmann, S. (2014). Interview: det kvalitative forskningsinterview som håndvark. København: Hans Reitzels Forlag.

Løw, O. (2017). Pcedagogisk Vejledning (2. udgave). Akademisk Forlag.

Mezirow, J. (1991). Transformative Dimensions of Adult Learning (Bd. 1991). Hentet fra //www.saxo.com/dk/transformative-dimensions-of-adult-learning_jackmezirow_hardback_9781555423391

Mezirow, J. (1998). On Čritical Reflection. Adult Education Quarterly, 48(3), 185-198.

Mezirow, J. (2012). Hvordan kritisk refleksion fører til transformativ læring. I K. Illeris (Red.), 49 tekster om laering (s. 156-172). Frederiksberg: Samfundslitteratur.

Nyvang, T., \& Dau, S. (2013). Læringsrum og vidensudvikling i professionuddannelser. Tidsskriftet Laring og Medier (LOM), 6(11). Hentet fra https://tidsskrift.dk/lom/article/view/8564

Onarheim, B., \& Wiltschnig, S. (2010). Opening and constraining: constraints and their role in creative processes. Proceedings of the 1st DESIRE Network Conference on Creativity and Innovation in Design, 83-89. Desire Network.

Perez, C. (2016). Innovations in simulation technology: with technological advancements and innovations, simulation technology continues to be a valuable tool in medical education. RT for Decision Makers in Respiratory Care, 29(5), 14-18.

Polit, D. F., \& Beck, C. T. (2018). Essentials of nursing research: appraising evidence for nursing practice (Ninth edition). Philadelphia: Wolters Kluwer Health.

Professionshøjskolen Absolon. (2013). Mange flere vælger e-læringsuddannelser - blended learning er fremtidens undervisningsform. Hentet 31. oktober 2018, fra DenOffentlige.dk website:

https://www.denoffentlige.dk/mange-flere-vaelger-e-laeringsuddannelser-blended-learning-er-fremtidensundervisningsform

Præstegaard, J. (2012). Fokusgruppeinterview. I S. Glasdam (Red.), Bachelorprojekter inden for det sundhedsfaglige område (1. udgave, Bd. 1-2. oplag, s. 109-118). København: Nyt Nordisk Forlag Arnold Busck A/S.

Refleksiv tænkning gennem simulation - University Colleges. (2011, 2017). Hentet 9. november 2017, fra UC Viden website: https://www.ucviden.dk/portal/da/projects/refleksiv-taenkning-gennemsimulation(d39a5081-5269-4ce4-b48e-f6e64e5c76c1).html

Schaarup, P. (2017). Projekt "Simulation med refleksivt potentiale” (s. 57) [Evalueringsrapport]. VIA University college: VIA University college. 
Srinivasan, M., Hwang, J. C., West, D., \& Yellowless, P. M. (2006). Assessment of Clinical Skills Using Simulator Technologies.pdf. Educational Assessment, Interventions, and Outcomes, 30(6), 505-515.

Uddannelses- og Forskningsministeriet. Bekendtgørelse om diplomuddannelser. , Pub. L. No. BEK nr 1008 (2016).

VIA Aftryk. (u.å.). Hentet 30. september 2018, fra https://www.via.dk/om-via/organisation/aftryk Wacherhausen, S. (2008). Refleksion og laering: refleksionens status som laringsfaktor i projektorganiserede undervisningsformer ved poedagoguddannelsen (Bd. 2008). Århus: RUML.

Wahlgren, B., Høyrup, S., Pedersen, K., \& Rattleff, P. (2013). Refleksion og laring: kompetenceudvikling $i$ arbejdslivet. Frederiksberg: Samfundslitteratur.

Wahlgren, B., \& Aarkrog, V. (2012). Transfer kompetence i en professionel sammenhoeng. Hentet fra http://site.ebrary.com/id/10607660 


\section{Forfattere}

\section{Betina Leth Leth}

Lektor

\section{VIA University College}

Betina er uddannet sygeplejerske og har en pædagogisk diplomuddannelse i psykologi og en Cand. Mag. i Læring og forandringsprocesser. Betina er ansat i VIA Efter og videreuddannelse inden for Social, sund og beskræftigelsesområdet, og sidder som modulansvarlig og underviser på de pædagogiske moduler på den sundhedsfaglige diplomuddannelse. Betina er forsknings- og udviklingsmæssigt optaget af pædagogisk og didaktisk brug af digitale medier og IKT i undervisningen, samt hvordan der kan skabes bedre transfer og effekt af kompetenceudvikling.

\section{Bente Riis}

Lektor

\section{VIA University College}

Bente er uddannet fysioterapeut og har en Master i professionsudvikling. Bente er ansat i VIA Efter og videreuddannelse inden for Social, sund og beskæftigelsesområdet, og er modulansvarlig og underviser på de pædagogiske moduler på den sundhedsfaglige diplomuddannelse. Bente er forsknings- og udviklingsmæssigt optaget af pædagogik og didaktik med fokus på vejledning - og hvordan vejledningskompetencer kan kvalificeres på forskellig vis $\mathrm{fx}$ i form af anvendelse af digitale medier.

\section{Lillian Buus}

Specialkonsulent, $\mathrm{PhD}$

VIA Læring og IT, VIA University College

Lillian har en PhD inden for Human Centred Informatic, med fokus på

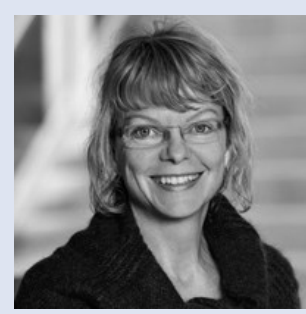
potentialer og udfordringer ved integration af web 2.0 medieret læring $\mathrm{i}$ undervisning. Fokus er bl.a. på understøttelse af underviserne i processen. Lillian er konstitueret centerleder for VIA Læring og IT samt specialkonsulent i Enheden for Læringsdesign, VIA University College. Lillian har forskningsmæssigt en interesse for pædagogisk og didaktisk brug af digitale medier og IKT i undervisning.

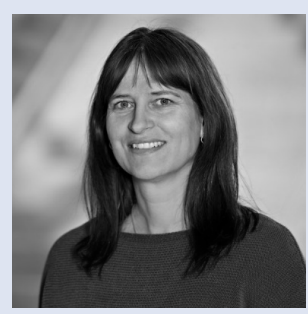

